\title{
OBITUARY
}

\section{Lionel Palmer Miles}

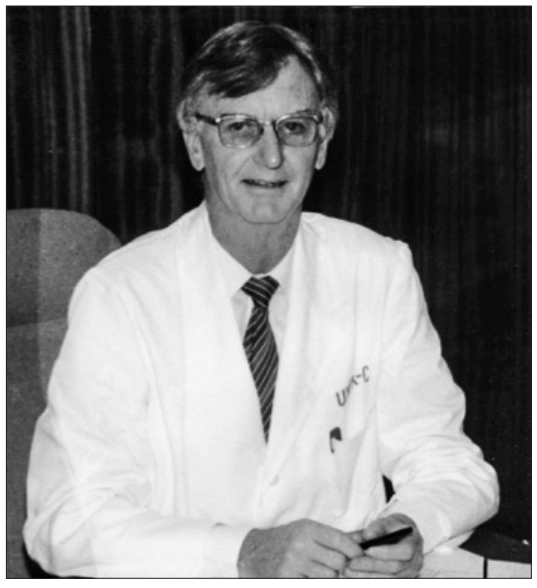

When the history of dental postgraduate studies at the University of the Western Cape (UWC), once fondly known as the Intellectual Home of the Left, is written, the name of Lionel Palmer Miles will be mentioned with great pride.

Lionel Miles was born in Molteno in the Eastern Cape on 5 February 1928. Having matriculated from Queen's College in Queenstown, he completed his dental degree at the University of the Witwatersrand in 1951, after which he opened a dental practice in Worcester. In 1960 he travelled to England, where he specialised in maxillofacial surgery at the East Grinstead Hospital and Queen
Mary's Hospital, Roehampton, under the tutelage of Sir Robert Bradlow, Sir Terence Ward and Mr Norman Rowe.

In London he met his future wife Marion, a Canadian-born nurse, and they married in 1963. They returned to South Africa in 1965, when Lionel was appointed as a full-time specialist in maxillofacial surgery at Groote Schuur Hospital (GSH), thereby becoming the first maxillofacial and oral surgeon south of the Vaal River. In 1968 he joined Prof. Manie Breytenbach in the first specialist maxillofacial and oral surgery practice in Cape Town, while continuing as a part-timer at GSH. Recognising the need for the postgraduate training of historically disadvantaged dentists, Lionel joined the Faculty of Dentistry at UWC in 1983, serving at the same time as Chair and Head of Maxillofacial Surgery at GSH. In 1987, he reluctantly accepted the post of Dean of Dentistry at UWC, a post he served with great distinction.

A deeply religious person, Lionel believed in fairness, justice and equality for all, and showed a deep compassion for humanity. When the divisions wreaked by the horrors of the apartheid system became visible in his professional life, Lionel, in his inimitable way, worked his quiet diplomacy and was able to transcend the many political, cultural and social barriers that were suffocating the university and teaching hospitals at that time.

A talented musician, Lionel was an accomplished pianist and organist and was choir master at the Church of the Good Shepherd - Protea. He was also a member of the Cape Town Male Choir.

His legacy is not simply in the pioneering of maxillofacial and oral surgery in Cape Town and at UWC, but can be found in the patients, students, academics, colleagues, worshippers, friends and family whose lives he touched.

Lionel passed away in Cape Town on 24 December at the age of 89 . He is survived by his wife Marion, children Jane and Gordon, and three grandchildren.

\section{Rushdi Hendricks}

University of Cape Town, South Africa

\section{Chris Naidoo}

South African National Defence Force

\section{Jairam Reddy}

University of the Western Cape, Cape Town, South Africa

\section{Peter Gordon}

University of Cape Town, South Africa

peter.gordon@uct.ac.za 